\title{
STRUKTUR KOMUNITAS MAKROZOOBENTHOS DI EMPAT MUARA SUNGAI CAGAR ALAM PULAU DUA, SERANG, BANTEN
}

\section{COMMUNITY STRUCTURE OF MACROZOOBENTHOS IN FOUR RIVERS AND ESTUARIES IN PULAU DUA NATURE CONSERVATION, SERANG, BANTEN}

\author{
Muhammad Ridwan ${ }^{1 *}$, Rizal Fathoni ${ }^{2}$, Ishma Fatihah', Danang Aji Pangestu'

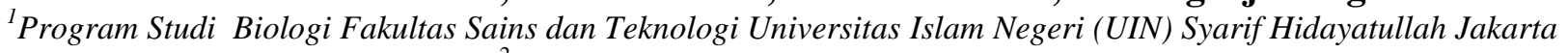 \\ ${ }^{2}$ Marine Biology Club (MBC) Nudibranch \\ *Corresponding author: ridwan_bio12@yahoo.co.id
}

Diterima: 16 Februari 2016. Direvisi: 1 Juni 2016. Disetujui: 10 Juni 2016.

\begin{abstract}
Abstrak
Penelitian ini dilaksanakan di sungai dan estuari yang berada di kawasan Cagar Alam Pulau Dua, Serang, Banten. Kawasan tersebut sering dimanfaatkan oleh warga setempat untuk pengairan tambak yang berada di luar kawasan. Aktivitas tersebut secara tidak langsung akan berpengaruh terhadap biota yang berada di sungai maupun estuari. Makrozoobenthos merupakan salah satu aspek biologis yang berperan penting dalam pengkajian kualitas suatu perairan. Tujuan penelitian ini adalah untuk mengetahui struktur komunitas makrozoobenthos yang berada di Cagar Alam Pulau Dua. Metode yang digunakan adalah survey deskriptif. Pengambilan sampel dilakukan secara purposive sampling dengan menetapkan 4 stasiun penelitian. Berdasarkan hasil penelitian ditemukan 9 jenis makozoobenthos yang dikelompokkan menjadi 6 famili, yaitu Grapsidae, Littorinidae, Panaeidae, Planaxidaae, Ocypodidae dan Potamididae. Indeks Keanekaragaman yaitu sebesar 0,693-1,646, nilai kemerataan jenis sebesar 0,149-0,457, dan nilai dominansi yaitu 0,5. Keanekaragaman dan dominansi menunjukkan nilai yang rendah. Dominansi Metopograpsus latiforus menyebabkan terganggu dan tidak stabilnya perairan di kawasan cagar alam.
\end{abstract}

Kata kunci: Makrozoobenthos; Pulau Dua; Struktur komunitas

\begin{abstract}
Research was carried out in rivers and estuaries in nature conservation Cagar Alam Pulau Dua, Serang, Banten. Those areas are often used by local residents to irrigate ponds outside the sites. That activity directly influences biota in the rivers and estuaries. Macrozoobenthos is one of biology aspects that play an important role in quality assessment of irrigation. This research aimed to study macrozoobenthos community structure in Cagar Alam Pulau Dua by using a descriptive survey method. Sample was collected by using a purposive sampling method and deciding 4 research sites. Research found 9 species of macrozoobenthos belonged to 6 families, namely Grapsidae, Littorinidae, Panaeidae, Planaxidaae, Ocypodidae, and Potamididae. Diversity index was 0,6931,646, evenness value was 0,149-0,457, and dominance value was 0,5. Diversity index and dominance value were indicated low. Dominance value of Metopograpsus latiforus led to unstable and damaging irrigation in nature conservation.
\end{abstract}

Keywords: Community structure; Macrozoobenthos; Pulau Dua

Permalink/DOI: http//:dx.doi.org/10.15408/kauniyah.v9i1.3256 


\section{PENDAHULUAN}

Cagar Alam Pulau Dua merupakan salah cagar alam yang berada di Provinsi Serang, Banten. Terdapat 9 anak sungai yang melewati kawasan ini, tiga diantaranya bermuara ke Cagar Alam Pulau Dua yaitu sungai Kepuh, Padek, dan Citangsi yang berasal dari aliran irigasi yang berada di bagian selatan Pulau Dua. Enam anak sungai lainnya yang mengalir dari Cagar Alam Pulau Dua yaitu sungai Cigenteng, Cipacar, Bistrik, Cirukem, Cikelapa, Citangsi yang merupakan tumpuan dari petani tambak tradisional yang dipergunakan untuk mengairi tambak-tambak yang berada disekitarnya. Semua sungai tersebut akan bermuara ke estuari yang berada di kawasan ini (Mariana \& Rozza, 2011).

Sungai dan estuari yang berada di kawasan cagar alam ini sering dimanfaatkan oleh warga setempat. Umumnya warga memanfaatkan sungai tersebut untuk pengairan tambak yang berada di luar kawasan tersebut. Sungai yang paling sering digunakan untuk pengairan tambak adalah Sungai Kepuh, Padek, Cigenteng, dan Cipacar. Hal inilah yang membuat secara tidak langsung akan berpengaruh terhadap biota yang berada di sungai maupun estuari. Dampak yang ditimbulkan dari usaha tambak ternyata cukup signifikan terhadap ekosistem estuari. Sisa pakan, kotoran dari budi daya organisme dan plankton yang mati serta material organik berupa padatan tersuspensi maupun terlarut yang terangkut lewat pemasukan air merupakan sumber bahan organik di lahan tambak (Rachmawaty, 2011) sehingga hal ini akan berdampak pada pencemaran perairan di muara sungai. Tidak hanya itu sisa pakan itu selanjutnya akan menjadi sumber limbah utama bahan organik dan nutrien ke lingkungan perairan. Menurut Barg (1992) limbah tersebut dapat menyebabkan hipernutrifikasi yang diikuti oleh perubahan ekologi fitoplankton, peningkatan sedimentasi, siltasi, hipoksia, perubahan produktivitas. Jika tetap dibiarkan maka ekosistem perairan akan rusak. Rusaknya ekosistem perairan tersebut akan berdampak juga terhadap kehidupan biota air seperti bentos yang biasanya hidup di dasar perairan, dimana penurunan kelimpahan dan komposisi dari organisme tersebut biasanya merupakan indikator adanya gangguan ekologi yang terjadi pada suatu perairan sungai (Doni, 2010).

Pengkajian kualitas di muara sungai dapat dilakukan dengan berbagai cara, seperti dengan analisis fisika dan kimia air serta analisis biologi. Untuk perairan yang dinamis, analisa fisika dan kimia air kurang memberikan gambaran yang sesungguhnya kualitas perairan, dan dapat memberikan penyimpangan-penyimpangan yang kurang menguntungkan, karena kisaran nilai-nilai peubahnya sangat dipengaruhi keadaaan sesaat. Bourdeau and Tresshow (1978) dalam Butler (1978) menyatakan bahwa dalam lingkungan yang dinamis, analisis biologi khususnya analisis struktur komunitas hewan bentos, dapat memberikan gambaran yang jelas tentang kualitas perairan. Salah satu aspek biologi yang paling sering dikaji dalam penilaian kualitas air adalah makrozoobenthhos. Menurut Pratiwi \& Astuti (2012), makrozoobenthos merupakan organisme yang hidup menetap (sesile) dan memiliki daya adaptasi yang bervariasi terhadap kondisi lingkungan. Selain itu tingkat keanekaragaman yang terdapat di lingkungan perairan dapat digunakan sebagai indikator pencemaran. Makrozoobenthos sangat baik digunakan sebagai bioindikator lingkungan perairan karena habiat hidupnya yang menetap (Darmono, 2001). Makrozoobenthos juga merupakan hewan yang sangat sensitif terhadap perubahan lingkungan dan paling banyak digunakan sebagai indikator pencemaran logam, karena habitat hidupnya yang menetap (Darmono, 2001).

Mengingat pentingnya peran makrozoobenthos di muara sungai dan belum adanya informasi serta data tentang makrozoobenthos di Cagar Alam Pulau Dua, maka perlu dilakukan penelitian tentang struktur komunitas makrozoobenthos di Cagar Alam Pulau Dua.

\section{MATERIAL DAN METODE Waktu dan Lokasi Penelitian}

Penelitian ini telah dilakukan pada Bulan Juli 2015 di 4 muara sungai yaitu Sungai Kepuh, Sungai Padek, Sungai Cigenteng dan Sungai Cipacar, yang berada di Cagar Alam 
Pulau Dua, Kabupaten Serang, Provinsi Banten dan secara geografis terletak $06^{\circ} 01^{\prime} \mathrm{LS}$ dan $106^{\circ} 12^{\prime} \mathrm{BT}$. Identifikasi sampel bentos dilakukan di Pusat Laboratorium Terpadu Fakultas Sains dan Teknologi Universitas Islam Syarif Hidayatullah Jakarta.

\section{Teknik Pengambilan Sampel dan Analisis Data}

Penelitian ini dilakukan dengan metode survei, sampel dikoleksi secara purposive sampling. Titik sampling pada setiap sungai ditentukan pada bagian hulu, tengah dan hilir, masing-masing dengan 3 kali ulangan.

Alat-alat yang digunakan dalam penelitian ini adalah termometer merk immersion, secchi disk, Eckman grab berukuran $25 \mathrm{~cm} \mathrm{x}$ $25 \mathrm{~cm}$, kantong plastik, spidol permanen, label, saringan bertingkat merk Restch, pinset merk Yamako, baki, botol film, mikroskop stereo merek Olympus, DO meter merek Lutron dan $\mathrm{pH}$ indikator merek Merck, kertas label, data sheet, buku identifikasi serta Conchology, (http://www.conchology.be), Field Guide to Survey and Manage Freshwater Mollusk Species (Frest \& Johannes, 1999), Keong Air Tawar Pulau Jawa (Ristiyanti et. al., 2012), dan The Fiddler Crabs (George \& Jones, 1982). Adapun untuk bahan-bahan yang digunakan adalah formalin $4 \%$, alkohol $70 \%$.

Pengumpulan sampel menggunakan Eckhman grab mempunyai ukuran bukaan 25 $\mathrm{cm}$ x $25 \mathrm{~cm}$. Eckhman Grab dimasukkan ke dasar sungai kemudian jatuhkan pemberat dari atas agar Eckhman Grab tertutup dan sampel masuk ke dalam Eckhman Grab. Sampel selanjutnya disaring dari substrat dasar atau lumpur menggunakan saringan bertingkat dan ditampung dalam plastik yang diberi formalin $4 \%$ sebanyak $1 \mathrm{ml}$ untuk pengawetan. Setelah itu ditutup dengan isolasi dan diberi label.

Pengukuran paramater fisik-kimia perairan dilakukan di setiap stasiun penelitian. Pengukuran fisik-kimia perairan dilakukan pada waktu siang hari (suhu, $\mathrm{pH}$ dan DO) serta ketika pasang dan surut (kedalaman kecerahan dan kecepatan arus).

Jenis yang telah ditemukan kemudian dihitung mengikuti indeks keanekaragaman (Krebs, 1989).

$$
\mathrm{H}^{\prime}=-\sum \mathrm{Pi} \ln \mathrm{Pi}
$$

Keterangan :

$\mathrm{Pi}=$ Jumlah individu dalam setiap jenis (ni) Jumlah total individu (N)

ni : jumlah individu jenis ke- $i$

$\mathrm{N}$ : jumlah seluruh individu

Kriteria :

$\mathrm{H}<1$ : keanekaragaman rendah, produktivitas rendah sebagai indikasi adanya tekanan yang berat dalam ekosistem.

$1<\mathrm{H}<3$ : keanekaragaman sedang, tekanan ekologis sedang, kondisi cukup seimbang.

$\mathrm{H}^{\prime}>3$ : keanekaragaman tinggi dan ekosistem stabil

Indeks kemerataan:

$$
\mathrm{E}=\mathrm{H}^{\prime} /(\log ) \mathrm{s}
$$

Keterangan :

H' : nilai keanekaragaman

s : jumlah jenis

E : nilai kemerataan

Pielou (1966) dalam Romimohtarto (2009)

Menurut Krebs (1989) nilai Indeks Keseragaman (E) berkisar antara 0-1. Nilai Indeks Keseragaman mendekati 0 berarti keseragamannya rendah karena ada jenis yang mendominasi, dan jika nilainya mendekati 1 , maka nilai keseragaman tinggi dan menggambarkan tidak ada jenis yang mendominansi sehingga pembagian jumlah individu masingmasing jenis sangat seragam atau merata.

Indeks dominansi digunakan untuk penentuan ada atau tidaknya organisme makrozoobentos yang mendominasi suatu perairan. Indeks ini dapat dinyatakan dalam rumus:

$$
c=\sum_{i=1}^{s}\left(\frac{n i}{N}\right)^{2}
$$

Keterangan :

$C \quad$ : Indeks dominansi

$\mathrm{N}$ : Jumlah total individu dari semua genus

$\mathrm{Ni}$ : Jumlah individu pada tingkat genus ke-i 
Nilai indeks dominansi (C) berkisar antara 0 sampai 1 , jika nilai $\mathrm{C}$ mendekati 0 berarti bahwa tidak ada individu yang mendominasi dan sebaliknya jika $\mathrm{C}$ mendekati 1 maka ada salah satu individu yang mendominasi (Odum, 1971).
HASIL

Komposisi Makrozoobenthos

Berdasarkan hasil penelitian yang dilakukan di 4 sungai di Cagar Alam Pulau Dua ditemukan 6 famili dan 9 jenis dengan total individu sebanyak 42 individu (Gambar 1).

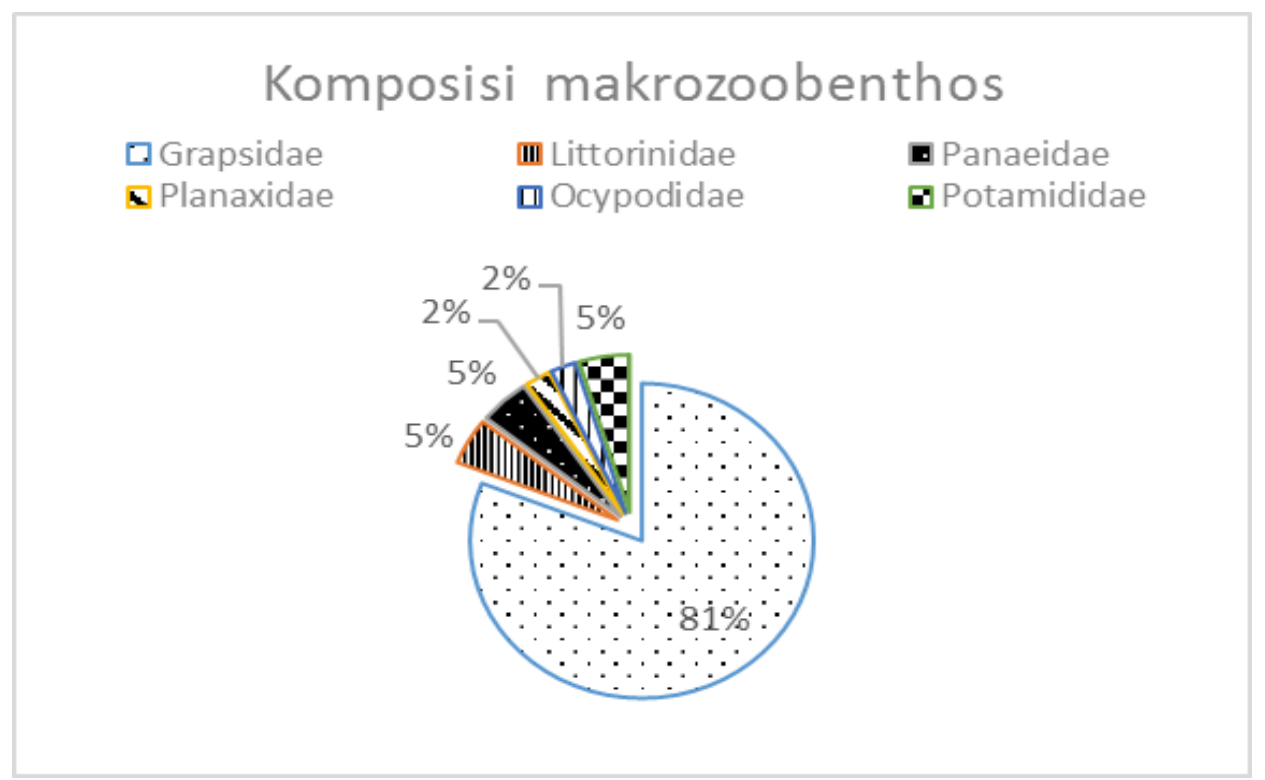

Gambar 1. Komposisi Makrozoobenthos di 4 Muara Sungai Cagar Alam Pulau Dua, Serang, Banten

\section{Struktur Komunitas Makrozoobenthos}

Keanekaragaman hayati merupakan ukuran kestabilan suatu ekosistem, jika makin beranekaragam jenis kehidupan dalam suatu habitat atau makin banyak populasi penyusun suatu komunitas, maka semakin stabil suatu ekosistem. Berikut hasil perhitungan indeks keanekaragaman (H'), kemerataan jenis (E) dan Dominansi (C) makrozoobenthos di Cagar Alam Pulau Dua, Serang, Banten.

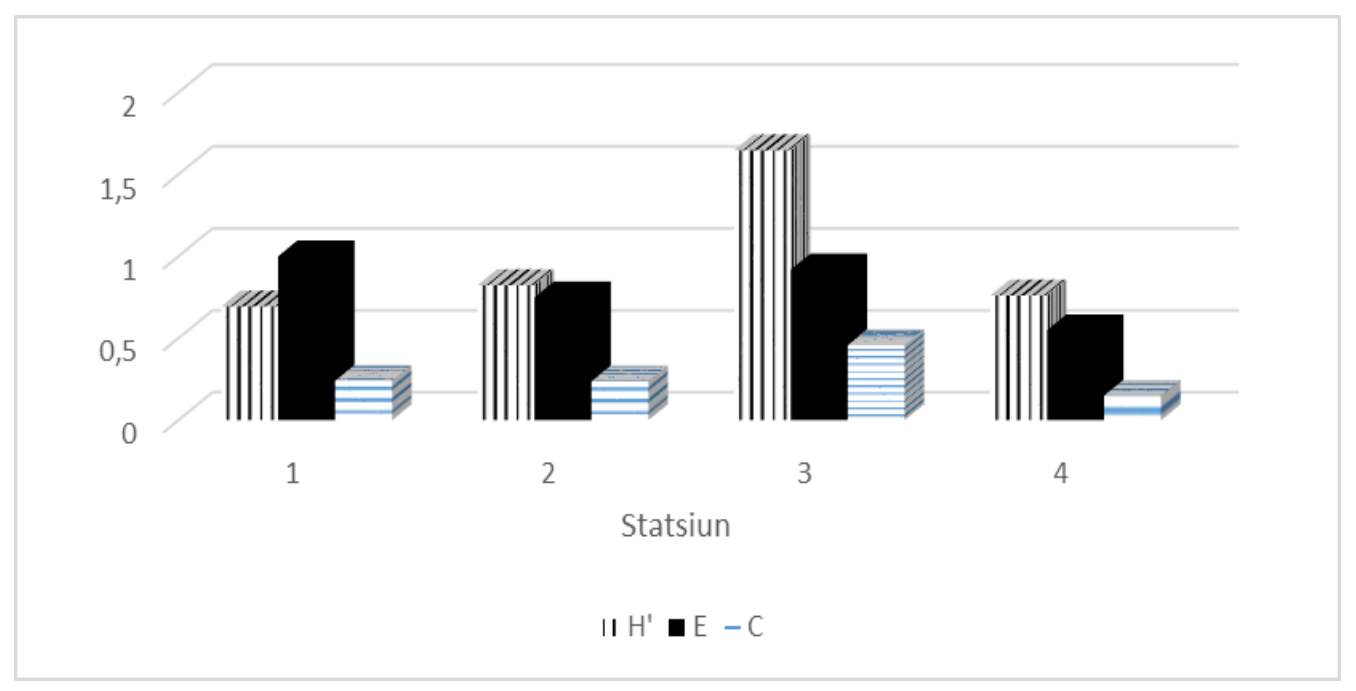

Gambar 2. Keanekaragaman, Kemerataan dan Dominansi makrozoobenthos di 4 muara sungai Cagar Alam Pulau Dua. 


\begin{tabular}{ccccccc}
\hline Stasiun & Suhu $\left({ }^{\circ} \mathbf{C}\right)$ & $\mathbf{p H}$ & DO & $\begin{array}{c}\text { Kedalaman } \\
(\mathbf{c m})\end{array}$ & $\begin{array}{c}\text { Kecerahan } \\
(\mathbf{c m})\end{array}$ & $\begin{array}{c}\text { Kec. arus } \\
(\mathbf{m} / \mathbf{s})\end{array}$ \\
\hline 1 & 35,3 & 8,0 & 11,7 & 12,7 & 9,2 & 0,1 \\
2 & 29,0 & 8,5 & 7,8 & 31,0 & 16,5 & 0,1 \\
3 & 32,0 & 8,0 & 8,0 & 23,3 & 16,3 & 0,0 \\
4 & 32,7 & 7,7 & 10,7 & 35,3 & 18,5 & 0,0 \\
\hline
\end{tabular}

Tabel 1. Nilai Rata-rata Pengukuran Faktor Kimia-Fisik di 4 Muara Sungai Cagar Alam Pulau Dua

\section{Faktor Fisik-Kimia Perairan}

Parameter Kimia-Fisik peraiaran merupakan salah indikator penting untuk mengetahui apakah telah terjadi pencemaran atau tidak. Kualitas perairan baru dapat dikatakan baik jika organisme tersebut dapat melakukan pertumbuhan dan perkembangbiakan dengan baik. Organisme perairan dapat hidup dengan layak jika faktor-faktor yang mempengaruhinya, seperti fisika-kimia perairan berada dalam batas toleransi yang dikehendaki. Berikut hasil pengukuran faktor fisika-kimia yang telah di ukur pada 4 stasiun pengamatan di Cagar Alam Pulau Dua.

\section{PEMBAHASAN}

\section{Komposisi Makrozoobenthos}

Berdasarkan komposisi diatas diketahui bahwa Famili Grapsidae memiliki komposisi yang paling besar yaitu sebesar $81 \%$ dan jenis yang paling banyak ditemukan yaitu Metopograpsus latiforus sebanyak 29 individu disekitar mangrove dan tempat yang berlumpur. Lingkungan hutan mangrove menyediakan habitat yang baik berbagai fauna dengan adanya substrat dasar yang ternaung pohon sebagai tempat menempel dan yang terpenting melimpahnya detritus organik sebagai sumber makanan (Hamidy, 2010). Hasil dari penelitian ini juga menemukan bahwa banyak jenis Kepiting yang tinggal di dalam lumpur. Tanah liat berlumpur akan mempermudah kepiting untuk membuat lubang dan disamping itu kandungan bahan organik untuk hidupnya juga melimpah. Kerapatan hutan mangrove memberikan perlindungan yang berarti bagi kehidupan bagi jenis-jenis kepiting. Substrat yang ditemukan dilokasi penelitian didominasi oleh tanah liat yang berlumpur, terutama daerah yang dekat dengan muara sungai (Hamidy, 2010). Adapun jenis-jenis makrozoobentos yang ditemukan adalah Parasesarma sp., Metopograpsus latiforus, Littorina littorea, Panaeus sp., Parasesarma erythodactyla, Planaxis sulcatus, Uca coarctata, Potamides lamarcki, dan Teleopium telescopium.

\section{Struktur Komunitas Makrozoobenthos}

Berdasarkan hasil penelitian ini diketahui nilai keanekaragaman makrozoobenthos pada tiap-tiap sungai berbeda. Diketahui bahwa nilai keanekaragaman pada sungai Kepuh yaitu 0,693 , sungai Padek yaitu 0,823 , sungai Cigenteng yaitu 1,646 dan Cipacar yaitu 0,76. Nilai keanekaragaman dari 4 stasiun ini tergolong dalam katagori buruk-sedang. Nilai keanekaragaman pada sungai kepuh, Padek dan Cipancar tergolong rendah, hal ini menunjukkan bahwa muara tersebut berada pada kondisi ekosistem yang tidak stabil. Hal ini dikarenakan pada ketiga sungai tersebut merupakan sungai yang paling sering digunakan dan dimanfaatkan untuk keperluan pengairan tambak dan sekaligus sebagai tempat pembuangan limbah yang berupa sisa pakan ataupun kotoran dari budi daya organisme dan plankton yang mati serta material organik berupa padatan tersuspensi maupun terlarut yang terangkut lewat pemasukan air merupakan sumber bahan organik di lahan tambak (Rachmawaty, 2011) sehingga hal ini akan berdampak pada pencemaran perairan di muara sungai. Nilai indeks keseragaman yang mendekati nol menurut Brower \& Zar (1977), merupakan nilai yang menunjukkan bahwa penyebaran jumlah individu atau jenis tidak 
sama atau tidak merata, terdapat individu yang jumlahnya melebihi (dominan) dibandingkan jenis yang lain. Penelitian lain yang dilakukan oleh Edward (2014) bahwa nilai keanekaragaman yang rendah disebabkan karena distribusi atau penyebaran makrozoobenthos yang tidak merata dalam komunitas.

Hasil selanjutnya yaitu pada sungai Cigenteng memiliki nilai keanekaragamn yang tergolong sedang. Hal ini menunjukkan bahwa kondisi ekosistem yang cukup seimbang dan tekanan ekologis sedang. Sungai Cigenteng juga diketahui merupakan sungai yang dimanfaatkan untuk pengairan tambak, namun berbeda dengan sungai yang lainnya, ukuran sungai ini jauh lebih besar disbandingkan dengan ketiga sungai lain. Clark (1974), mengatakan bahwa suatu keanekaragaman mengekspresikan variasi jenis yang ada dalam suatu ekosistem, ketika suatu ekosistem memiliki indeks keanekaragaman yang tinggi maka ekosistem tersebut cenderung seimbang. Sebaliknya, jika suatu ekosistem memilki indeks keanekaragaman yang rendah maka mengindikasikan ekosistem tersebut dalam keadaan tertekan atau terdegradasi.

Menurut Dahuri \& Arumsyah (1994) menyatakan bahwa indeks keseragaman (E) digunakan untuk melihat apakah didalam komunitas jasad akuatik yang diamati, terdapat pola dominansi oleh satu atau beberapa kelompok jenis jasad. Apabilah nilai E mendekati 1, maka sebaran individu-individu antar jenis relatif merata. Tetapi jika nilai $\mathrm{E}$ mendekati 0 , terdapat sekelompok jenis tertentu yang jumlahnya relatif berlimpah (dominan) daripada jenis lainnya.

Dominansi dinyatakan sebagai kekayaan jenis suatu komunitas serta keseimbangan jumlah individu setiap jenis. Nilai indeks dominansi yang didapat dari penelitian ini yaitu berkisar 0,149-0,457. Nilai ini menunjukkan bahwa adanya dominansi suatu jenis dalam suatu ekosistem. Adanya dominanasi menandakan bahwa tidak semua makrozoobenthos memiliki daya adaptasi dan kemampuan bertahan hidup yang sama di suatu tempat. Hal ini juga berarti makrozoobenthos di lokasi pengamatan tidak memanfaatkan sumberdaya secara merata (Rahma, 2005). Hal ini sesuai dengan pernyataan Odum (1993) yang menyatakan bahwa nilai indeks dominansi yang tinggi menyatakan konsentrasi dominansi yang tinggi (ada individu yang mendominansi), sebaliknya nilai indeks dominansi yang rendah menyatakan konsentrasi yang rendah (tidak ada yang dominan). Penelitian yang dilakukan oleh Zulkifli et al.,(2012) menunjukkan bahwa terdapat 2 jenis makrozooben-thos yang mendominasi dan dapat dijadikan sebagai bioindikator pencemaran bahan organik yaitu Melanoides sp. dan Amnicola sp.

Metopograpsus latifrons diketahui merupakan jenis yang mendominasi dan dapat ditemukan hampir di semua titik pengambilan sampel. Metopograpsus latifrons merupakan jenis kepiting yang umumnya hidup dalam lumpur, dekat dengan ekosistem mangrove dan muara sungai. Metopograpsus latifrons memiliki kemampuan mobilisasi yang tinggi sehingga dapat berpindah lokasi dengan mudah, sehingga hal inilah yang membuat spesies ini dapat ditemukan hampir disetiap titik pengambilan sampel (Bagus \& Aunurohim, 2013). Adanya dominansi karena kondisi lingkungan yang sangat menguntungkan dalam mendukung pertumbuhan jenis tertentu. Selain itu dominansi juga dapat terjadi karena adanya perbedaan daya adaptasi tiap jenis terhadap lingkungan. Menurut Odum \& Eugene (1993), nilai indeks dominani berkisar antara 1-0. Semakin mendekati satu, maka semakin tinggi tingkat dominansi jenis tertentu, sebaliknya bila nilai mendekati 0 berarti tidak ada jenis yang mendominansi.

Dominansi dinyatakan sebagai kekayaan jenis suatu komunitas serta keseimbangan jumlah individu setiap jenis. Nilai indeks dominansi yang didapat dari penelitian ini yaitu berkisar 0,149-0,457. Nilai ini menunjukkan bahwa adanya dominansi suatu jenis dalam suatu ekosistem. Adanya dominansi menandakan bahwa tidak semua makrozoobenthos memiliki daya adaptasi dan kemampuan bertahan hidup yang sama di suatu tempat. Hal ini juga berarti makrozoobenthos di lokasi pengamatan tidak memanfaatkan sumberdaya secara merata (Rahma, 2005). Hal ini sesuai dengan pernyataan Odum (1993) yang menya- 
takan bahwa nilai indeks dominansi yang tinggi menyatakan konsentrasi dominansi yang tinggi (ada individu yang mendominansi), sebaliknya nilai indeks dominansi yang rendah menyatakan konsentrasi yang rendah (tidak ada yang dominan).

\section{Faktor Fisik Kimia Perairan}

Suhu air merupakan salah satu faktor yang dapat mempengaruhi aktivitas serta memacu atau menghambat perkembangbiakan organisme perairan. Pada umumnya peningkatan suhu air sampai skala tertentu akan mempercepat perkembangbiakan organisme perairan. Berdasarkan hasil pengukuran faktor fisik kimia perairan diketahui bahwa kisaran suhu dari keempat muara sungai yaitu $29-35,3^{\circ} \mathrm{C}$. Suhu di wilayah muara sungai bervariasi, airnya lebih cepat panas dan lebih cepat dingin bergantung kondisi atmosfer yang ada. Suhu perairan pada kisaran ini masih mendukung proses metabolisme organisme yang hidup didalamnya (Nybakken, 1992). Hasil ini diketahui bahwa kisaran suhu tersebut merupakan kisaran yang mampu mendukung kehidupan makrozoobenthos. Menurut Lusianingsih (2011) suhu yang optimum bagi kehidupan makrozoobnethos yaitu berkisar 20$30^{\circ} \mathrm{C}$. Nilai kisaran ini mampu mendukung hidup yang layak dalam ekosistem dimana mereka hidup.

$\mathrm{pH}$ merupakan faktor pembatas bagi organisme yang hidup pada suatu perairan. Hasil pengukuran $\mathrm{pH}$ diketahui bahwa kisaran $\mathrm{pH}$ pada 4 muara sungai Cagar Alam Pulau Dua yaitu berkisar 7,7-8,5. Nilai $\mathrm{pH}$ ini merupakan kisaran yang mampu mendukuang kehidupan makrozoobenthos. Hal ini sesuai dengan pernyataan Effendi (2003) bahwa sebagian besar biota akuatik sensitif terhadap perubahan pH dan menyukai kisaran ph sekitar 7-8,5.

Berdasarkan hasil pengukuran DO diketahui bahwa nilai DO di 4 muara sungai yaitu berkisar 7,8-11,7 mg/L. Kandungan oksigen terlarut mempengaruhi jumlah dan jenis makrozoobenthos perairan. Tingginya nilai DO yang berada di 4 muara sungai Cagar Alam Pulau Dua ini tergolong sangat baik, hal ini dimungkinkan adanya pengaruh dari penggolakan massa air yang diakibatkan oleh arus.
Menurut Sastrawijaya (1991) kehidupan makrozoobenthos dapat bertahan jika ada oksigen terlarut minimum sebanyak $5 \mathrm{mg} / \mathrm{l}$, selebihnya tergantung kepada ketahanan organisme, derajat keaktifan, kehadiran pencemar, temperatur air dan sebagainya. Kandungan oksigen terlarut mempengaruhi jumlah jenis bentos di perairan, semakin tinggi kadar oksigen semakin besar kandungan oksigen dalam ekosistemnya. Dengan demikian semakin baik pula kehidupan makrozoobenthos yang mendiaminya.

Hasil selanjutnya yaitu kedalaman, diketahui bahwa kedalaman di 4 muara Cagar Alam Pulau Dua yaitu berkisar 12,7-35,3 cm. Adanya perbedaan ini dikarenakan adanya pengaruh pasang surut air laut, sehingga pada saat pasang permukaan air laut akan menjadi tinggi dan menyebabkan kedalaman air menjadi bertambah dan sebaliknya apabila surut permukaan air laut akan menjadi rendah dan menyebabkan kedalaman air menjadi berkurang (Yulia et. al., 2012). Hal yang sama juga diungkapkan oleh Odum (1996) dalam Irmawan et. al. (2010) bahwa kedalaman perairan mempengaruhi jumlah jenis makrozoobenthos. Semakin dalam dasar suatu perairan, semakin sedikit jumlah jenis makrozoobenthos karena hanya makrozoobenthos tertentu yang dapat beradaptasi dengan kondisi.

Kecerahan suatu perairan erat hubungannya dengan penetrasi cahaya yang masuk ke dalam kolom perairan tersebut. Berdasarkan hasil penelitian ini diketaui bahwa nilai kecerahan 9,2-18,5 cm. Penelitian yang dilakukan oleh Yulia et. al. (2012) bahwa kecerahan perairan Morosari pada bulan AprilJuni berkisar 9-67.5 cm. Hal ini menunjukkan bahwa kecerahan di 4 muara Cagar Alam Pulau Dua tergolong rendah. Rendahnya kecerahan dipengaruhi oleh partikel-partikel dan sedimen yang hanyut terbawa aliran sungai dari hasil pengikisan daratan dan musim penghujan (Sinambela \& Sipayung, 2015).

Kecepatan arus juga merupakan salah satu faktor fisik yang mempengaruhi keberadaan makrozoobenthos. Berdasarkan hasil pengukuran diketahui bahwa keceparan arus di 4 muara hanya berkisar $0-0,1 \mathrm{~m} / \mathrm{s}$. Hal ini dikarenakan saat pengukuran kondisi muara 
sedang surut dan sedang musim kemarau sehingga kecepatan arus yang terukur sangat rendah. Menurut Barus (2002) bahwa kecepatan arus dipengaruhi kekuatan angin, topografi, kondisi pasang surut dan musim. Pada saat musim penghujan, akan meningkat debit air dan sekaligus mempengaruhi kecepatan arus, selain itu adanya bentuk alur sungai dan kondisi substrat pada dasar perairan menyebabkan keceapatan arus bervairasi. Selain itu substrat yang ditemukan saat penelitian ini adalah substrat lumpur yang sedikit berpasir. Jenis substrat diketahui dipengaruhi oleh kecepatan arus, pada kecepatan arus yang tinggi dalam perairan akan menyebabkan tipe substrat di perairan tersebut didominasi oleh tipe substrat berpasir, karena yang mampu diendapkan di dasar perairan tersebut adalah partikelpartikel yang berukuran besar seperti kerikil aItau pasir, sedangkan partikel yang halus terus terbawa oleh arus yang kuat. Sedangkan pada arus yang lemah dalam suatu perairan menyebabkan perairan tersebut didominasi oleh substrat berlumpur atau lempung (Husnayati et. al., 2015).

\section{KESIMPULAN}

Di muara sungai Cagar Alam Pulau Dua ini ditemukan 6 jenis makrozoobenthos yang terdiri dari Grapsidae, Littoridae, Panaeidae, Planaxidae dan Potamidae. Keanekaragaman dan dominansi menunjukkan nilai yang rendah. Keberadaan Metopograpsus latiforus yang jumlah individunya lebih banyak dibandingkan jenis-jenis lainnya menandakan bahwa kondisi muara sungai cagar alam terganggu dan tidak stabil.

\section{REFERENSI}

Bagus, K. S. \& Anunurohim. (2013). Studi distribusi makrofauna benthos di zonasi mangrove Pulau Poteran, Madura, Jawa Timur. Jurnal Sains dan Seni Pomits, 2(1), 1-5.

Barus, T. A. (2002). Pengantar limnologi. Medan: Universitas Sumatera Utara.

Barg, U. C. (1992). Guidelines of the promotion of environmental management of coastal aquaculture development. Rome: FAO Fisheries Technical Paper.
Brower, J. E. \& Zar, J. H. (1977). Field and laboratory methods for general ecology. USA: Brown Co Publisher.

Butler, G. C. (1978). Principles of ecotoxicology scope 12. New York: John Willey $\&$ Sons.

Clark, J. (1974). Coastal ecosystem: Ecological consederation for management of the coastal zone the conservation foundation. Washington, D.C.: The Conservation Foundation.

Dahuri, R. \& Arumsyah, S. (1994). Ekosistem pesisir. marine and mangement training. (Makalah). Pusat Studi Lingkungan Universitas Nusa Cendana, Kupang. NTT.

Darmono. (2001). Logam dalam sistem biologi makhluk hidup. Jakarta: UI Press.

Doni, S. (2010). Studi komunitas makrozoobenthos sungai Musi sekitar kawasan industri bagian hilir kota Palembang. Prosiding Seminar Nasional V Limnologi, 210-228.

Edward, A. (2014). Kelimpahan makrozoobenthos di perairan Situ Pamulang. AlKauniyah Jurnal Biologi, 7(2), 69-73.

Effendi, H. (2003). Telaah kualitas air bagi pengelolaan sumber daya dan lingkungan perairan. Jakarta: Kanisius.

George, R. W., \& Jones, D. S. (1982). A revision of the fiddler crabs of Australia (Ocypodinae: Uca). Australia: Western Australian Museum.

Hamidy, R. (2010). Struktur dan keragaman komunitas kepiting di kawasan hutan mangrove stasiun kelautan Universitas Riau Desa Purnama Dumai. Jurnal Ilmu Lingkungan. 2(4), 81-91.

Husnayati, H., Arthana, I. W. \& Wiryatno, J. (2015). Struktur komunitas makrozoobenthos pada tiga muara sungai sebagai bioindikator kualitas perairan di pesisir pantai Ampenan dan pantai Tanjung Karang Kota Mataram Lombok. Ecotropic, 7(2), 116-125.

Irmawan. R. N., Zulkifli, H. \& Hendri, M. (2010). Struktur komunitas makrozoobenthos di Estuaria Kuala Sugihan Provinsi Sumatera Selatan. Jurnal Ilmiah Marine Science Research, 1(1), 53-58. 
Krebs, C. J. (1989). Ecology methodology. New York: Harper Collin Publisher.

Lusianingsih, N. (2011). Keanekragaman makrozoobenthos di Sungai Bah Bolon Kabupaten Simamulung Sumatera Utara. (Skripsi). Fakultas Matematika dan Ilmu Pengetahuan Alam. Universitas Sumatera Utara.

Mariana, T. \& Rozza, T. K. (2011). Pengelolaan Cagar Alam Pulau Dua di Provinsi Banten sebagai ekosistem bernilai penting. Jurnal Penelitian dan Konservasi Alam, 8(1), 95-108.

Nybakken, J. W. (1992). Biologi laut suatu pendekatan ekologis. Alih bahasa oleh M. Eidman., Koesoebiono., D.G. Bengen, M. Hutomo \& S. Sukardjo. Jakarta: Gramedia Pustaka Utama.

Odum, E. P. (1971). Fundamentals of ecology. W.B. Philadelphia: Sounders Company Ltd.

Odum, E. P. \& Eugene, P. (1993). Dasardasar ekologi. Edisi Ketiga. Yogyakarta: Gadjah Mada University Press.

Pratiwi, R. \& Astuti, O. (2012). Biodiversitas krustasea (Decapoda, Brachyura, macrura) dari ekspedisi perairan Kendari 2011. Jurnal Ilmu Kelautan, 17(1), 8-14.

Purnama, P. R., Nastiti, N. W., Agustin, M. E., \& Affandi, M. (2011). Diversitas Gastropoda di Sungai Sukamade, Taman Nasional Meru Betiri, Jawa Timur. Berkala Penelitian Hayati, 16, 143-147.

Rachmawaty. (2011). Indeks keanekaragaman makrozoobenthos sebagai bioindikator tingkat pencemaran di Muara Sungai Jeneberang. Jurnal Bionature, 12(2), 103-109.
Rahma, Y. F. (2005). Keanekaragaman dan kemelimpahan makrozoobenthos di Hutan Mangrove hasil rehabilitasi Taman Hutan Raya Ngurah Rai Bali. Jurnal Biodiversitas, 7(1), 67-72.

Ristiyanti, Marwoto, M., Isnaningsih, N. R., Mujiono, N., Heryanto, Alfiah, \& Riena. (2012). Keong air tawar Pulau Jawa (Moluska, Gastropoda). Bogor: Pusat Penelitian Biologi Lembaga Ilmu Pengetahuan Indonesia.

Romimohtarto, K. (2009). Biologi laut: Ilmu pengetahuan tentang biota laut. Jakarta: Djambatan.

Sastrawijaya, A. T. (1991). Pencemaran lingkungan hidup. Jakarta: Rineke Cipta.

Sinambela, M. \& Sipayung, M. (2015). Makrozoobenthos dengan paramater fisika dan kimia di Perairan Sungai Babura Kabupaten Deli Serdang. Jurnal Biosains, $1(2), 44-50$

Frest, T. J., \& Johannes, E. J. (1999). Field guide to survey and manage freshwater mollusk species. Oregon: Bureau of Land Management.

Yulia, U., Widianingsih, \& Muhammad, Z. (2012). Struktur komunitas makrozoobenthos di perairan wilayah Morosari desa Bedono Kecamatan Sayung Demak. Journal of Marine Research, 1(2), 188196.

Zulkifli, H., Hanafiah, Z. \& Puspitawati, D. A. (2012). Struktur dan fungsi makrozoobenthos di Perairan Sungai Musi, Palembang: Telaah indikator pencemaran air. Prosiding Seminar Nasional Biologi di Medan, 586-595. 